\title{
Identification and characterization of alkaline serine protease from goat skin surface metagenome
}

\author{
Paul Lavanya Pushpam, Thangamani Rajesh, Paramasamy Gunasekaran*
}

\begin{abstract}
Metagenomic DNA isolated from goat skin surface was used to construct plasmid DNA library in Escherichia coli DH10B. Recombinant clones were screened for functional protease activity on skim milk agar plates. Upon screening 70,000 clones, a clone carrying recombinant plasmid pSP1 exhibited protease activity. In vitro transposon mutagenesis and sequencing of the insert DNA in this clone revealed an ORF of 1890 bp encoding a protein with 630 amino acids which showed significant sequence homology to the peptidase S8 and S53 subtilisin kexin sedolisin of Shewanella sp. This ORF was cloned in pET30b and expressed in E. coli BL21 (DE3). Although the cloned Alkaline Serine protease (AS-protease) was overexpressed, it was inactive as a result of forming inclusion bodies. After solubilisation, the protease was purified using Ni-NTA chromatography and then refolded properly to retain protease activity. The purified AS-protease with a molecular mass of $\sim 63 \mathrm{kDa}$ required a divalent cation $\left(\mathrm{Co}^{2+}\right.$ or $\left.\mathrm{Mn}^{2+}\right)$ for its improved activity. The $\mathrm{pH}$ and temperature optima for this protease were 10.5 and $42^{\circ} \mathrm{C}$ respectively.
\end{abstract}

\section{Introduction}

Proteases are present in all living forms as they are involved in various metabolic processes. They are mainly involved in hydrolysis of the peptide bonds (Gupta et al. 2002). Proteases are classified into six types based on the functional groups in their active sites. They are aspartic, cysteine, glutamic, metallo, serine, and threonine proteases. They are also classified as exo-peptidases and endo-peptidases, based on the position of the peptide bond cleavage. Proteases find a wide range of applications in food, pharmaceutical, leather and textile, detergent, diagnostics industries and also in waste management (Rao et al. 1998). Thus, they contribute to almost $40 \%$ of enzyme sales in the industrial market. Though proteases are found in plants and animals, microbial proteases account for two-third of share in the commercially available proteases (Kumar and Takagi 1999).

Proteases are also classified as acidic, neutral or alkaline proteases based on their $\mathrm{pH}$ optima. The largest share of the enzyme market is occupied by detergent proteases, which are mostly alkaline serine protease and active at

\footnotetext{
* Correspondence: gunagenomics@gmail.com

Department of Genetics, Centre for Excellence in Genomic Sciences, School of Biological Sciences, Madurai Kamaraj University, Madurai, India 625021.
}

neutral to alkaline $\mathrm{pH}$ range. Alkaline serine proteases have Aspartate (D) and Histidine $(\mathrm{H})$ residues along with Serine (S) in their active site forming a catalytic triad (Gupta et al. 2002). Serine proteases contribute to one third of the share in the enzyme market and are readily inactivated by Phenyl Methane Sulfonyl Fluoride (PMSF) (Page and Di Cera 2008). Based on the sequence and structural similarities, all the known proteases are classified into clans and families and are available in the MEROPS database (Rawlings and Barrett 1993).

Several microbial proteases from the culturable organisms have been characterized. However, very few proteases have been identified through culture independent metagenomic approach (Schloss and Handelsman 2003). In metagenomics study, the total nucleic acid content of the environmental samples is analysed. The DNA may be isolated by direct or indirect methods followed by purification (Gabor et al. 2003); Rajendhran and Gunasekaran 2008). Metagenomics approach has been recently employed in identifying number of novel genes encoding biocatalysts or molecules which are of pharmaceutical and industrial importance. Interestingly, the metagenomic libraries were mainly screened for enzymes like lipases and esterases (Lee et al. 2004; Rhee et al. 2005; Voget et al. 2003), proteases (Lee et al. 2007), amylases

\section{SpringerOpen ${ }^{\circ}$}

(c) 2011 Lavanya et al; licensee Springer. This is an Open Access article distributed under the terms of the Creative Commons Attribution License (http://creativecommons.org/licenses/by/2.0), which permits unrestricted use, distribution, and reproduction in any medium, provided the original work is properly cited. 
(Rondon et al. 2000; Voget et al. 2003), chitinase (Cottrell et al. 1999) and nitrilases (Robertson et al. 2004). Despite the success rate, very few attempts were made on the identification of proteases from metagenomic libraries. We report here an Alkaline Serine protease (AS-protease), identified from the goat skin metagenomic library, which showed homology to peptidase S8 and S53 subtilisin kexin and sedolisin of Shewanella sp. Surprisingly, this AS-protease requires $\mathrm{Co}^{2+}$ or $\mathrm{Mn}^{2+}$ metal ions for its improved activity.

\section{Materials and methods}

Materials, bacterial strains and culture conditions

Goat skins were obtained from butcheries in and around Madurai for metagenomic DNA isolation. Reagents for PCR, Taq DNA polymerase, oligonucleotide primers, and all biochemicals were from Sigma-Aldrich (St. Louis, MO, USA). T4 DNA ligase and restriction enzymes were from MBI Fermentas (Opelstrasse, Germany). Escherichia coli strains and plasmids used in this study are listed in Table 1. E. coli DH5 $\alpha$ and E. coli BL21 (DE3) were used for gene cloning and protein expression studies respectively.

\section{DNA manipulation techniques}

Standard procedures for plasmid isolation, restriction enzyme digestion, ligation, competent cell preparation and transformation were used as described by (Sambrook et al. (1989)). Metagenomic DNA was isolated using a modified indirect DNA extraction method (Gabor et al. 2003). The goat skin $(10 \mathrm{~cm} \times 10 \mathrm{~cm})$ was suspended in $0.75 \%(\mathrm{w} / \mathrm{v}) \mathrm{NaCl}$ and kept under agitation at $180 \mathrm{rpm}$ for $30 \mathrm{~min}$. The supernatant was collected and a pellet was obtained by centrifugation $(10,000 \times \mathrm{g}$ for $10 \mathrm{~min}$ at $4^{\circ} \mathrm{C}$ ). The pellet was rinsed and suspended in blending buffer (100 mM Tris- $\mathrm{HCl}$ [pH 8.0], $100 \mathrm{mM}$ sodium EDTA [pH 8.0], 0.1\% SDS) and homogenized. The homogenized mixture was subjected to low-speed centrifugation $\left(1000 \times g\right.$ for $10 \mathrm{~min}$ at $\left.10^{\circ} \mathrm{C}\right)$, and the supernatant containing bacterial cells was collected, while the coarse particles and high molecular weight DNA in the pellet was subjected to further centrifugation cycles as described above. Supernatant obtained from the three rounds of cell extraction were pooled. The supernatant were centrifuged at $10,000 \times g$ for $30 \mathrm{~min}$ at $4^{\circ} \mathrm{C}$ and the cell pellet was rinsed with chrombach buffer (0.33 M Tris- $\mathrm{HCl}, 1 \mathrm{mM}$ EDTA, $\mathrm{pH} 8)$. Then the mixture was suspended in lysis buffer (100 mM Tris- $\mathrm{HCl}, 100 \mathrm{mM}$ EDTA, $1.5 \mathrm{M} \mathrm{NaCl}$ ), in the presence of $0.1 \mathrm{mg}$ of proteinase $\mathrm{K}$ and $1 \mathrm{mg}$ of lysozyme and incubated at $37^{\circ} \mathrm{C}$ for $30 \mathrm{~min}$. Lysis was completed by adding $1 \mathrm{ml}$ of $20 \%$ SDS and incubated for $2 \mathrm{~h}$ at $65^{\circ} \mathrm{C}$ with shaking every $30 \mathrm{~min}$. The supernatant was collected by centrifugation at $6000 \times g$ for $10 \mathrm{~min}$ at $30^{\circ} \mathrm{C}$ and the pellets were re-extracted twice with $1 \mathrm{ml}$ lysis buffer, vortexing for a few seconds, and incubating at $65^{\circ} \mathrm{C}$ for $10 \mathrm{~min}$. The supernatant was extracted with equal volume of chloroform: isoamyl alcohol (24:1). DNA in the aqueous phase was precipitated by addition of 0.6 volumes of isopropanol and incubated at $-20^{\circ} \mathrm{C}$ for $1 \mathrm{~h}$. The precipitate was collected by centrifugation at $10,000 \times \mathrm{g}$ for $15 \mathrm{~min}$ at $4^{\circ} \mathrm{C}$ and then washed with $70 \%$ ethanol. The DNA pellet was suspended in $200 \mu \mathrm{l}$ TE buffer $(10 \mathrm{mM}$ Tris- $\mathrm{HCl}, 1 \mathrm{mM}$ EDTA, $\mathrm{pH}$ 8) and stored at $-20^{\circ} \mathrm{C}$.

Metagenomic DNA was partially digested with HindIII and the DNA fragments ranging about 3-8 kb were separated with QIAquick gel extraction kit (Qiagen, Hilden, Germany) and cloned into pUC19, resulting in plasmid pSP1 which was transformed into E. coli DH10B by electroporation (200 $\Omega, 25 \mu \mathrm{F}$ and $2.5 \mathrm{kV}$ ) using Gene Pulser (Bio-Rad, USA). Transformants were

Table 1 List of bacterial strains and plasmids used in this study

\begin{tabular}{|c|c|c|}
\hline Strains/plasmids & Genotype/Description & Reference/Source \\
\hline E. coli $\mathrm{DH} 5 \alpha$ & $\begin{array}{l}\mathrm{F}^{-} \text {endA1 glnV44 thi-1 recA1 relA1 gyrA96 deoR nupG } \Phi 80 \text { dlacZ } \triangle M 15 \triangle \text { (lacZYA-argF) } \\
\left.\text { U169, hsdR17( } r_{K}^{-} m_{K}^{+}\right), \lambda \text { - }\end{array}$ & Invitrogen (CA, USA) \\
\hline E. coli DH10B & 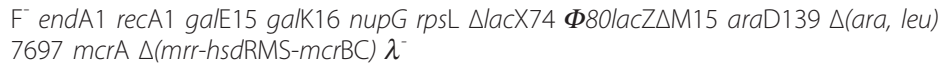 & Invitrogen (CA, USA) \\
\hline E. coli BL21 (DE3) & $\mathrm{F}^{-}$ompT gal dcm lon hsdS ${ }_{B}\left(r_{B}^{-} m_{B}^{-}\right) \lambda(\mathrm{DE} 3$ [lad ladUV5-T7 gene1 ind1 sam7 nin5]) & Novagen (CA, USA) \\
\hline pUC19 & $A p^{r} ;$ Cloning vector & Stratagene (CA, USA) \\
\hline pTZ57R/T & $A p^{r} ;$ PCR cloning vector & MBI Fermentas (Opelstrasse, Germany) \\
\hline pET30b & $K n^{r}$; Expression vector; T7 promoter & Novagen (CA, USA) \\
\hline pSP1 & pUC19 harbouring the AS-protease ORF; $A p^{r}$ & This study \\
\hline pTSP1 & AS- Protease ORF cloned in pTZ57R/T; $A p^{r}$ & This study \\
\hline pETP1 & AS- protease ORF cloned in pET30b; $K n^{r}$ & This study \\
\hline
\end{tabular}


selected on LB agar plates supplemented with $100 \mu \mathrm{g}$ of ampicillin/ml, X-gal $(20 \mu \mathrm{g} / \mathrm{ml})$ and IPTG $(40 \mu \mathrm{g} / \mathrm{ml})$ and incubated at $37^{\circ} \mathrm{C}$ for overnight. The white recombinant clones were scored and maintained.

Screening the metagenomic library for proteolytic activity The recombinant clones were screened for proteolytic activity on LB agar ampicillin plates supplemented with $1 \%(\mathrm{w} / \mathrm{v})$ skim milk (Lee et al. 2007) and incubated at $37^{\circ} \mathrm{C}$ for $48-72 \mathrm{~h}$. Proteolytic clones were selected based on the formation of zone of clearance around the colony.

\section{In vitro transposon mutagenesis and sequencing}

The recombinant plasmid was used as template for in vitro transposon mutagenesis using Template Generation System II kit (TGS, F-702; Finnzyme, Finland). E. coli DH10B carrying the plasmid pSP1 was transformed with the artificial $\mathrm{Mu}$ transposon by electroporation and the transformants were selected on LB agar plates containing ampicillin $(100 \mu \mathrm{g} / \mathrm{ml})$ and kanamycin $(30 \mu \mathrm{g} / \mathrm{ml})$. Further, the strains carrying the plasmid with the mutated protease were screened on $1 \%$ skim milk-LB agar plate for a negative activity. The plasmids from the mutants were isolated and the regions adjacent to the transposons were sequenced using transposon specific primer. BlastN and BlastP analyses were carried out to find sequence identity and homology (Altschul et al. 1990). Signal peptide of the protein was predicted using the SignalP 3.0 server http:// www.cbs.dtu.dk/services/SignalP/ (Bendtsen et al. 2004). Multiple sequence alignment was performed with the sequences (MER048892; Shewanella baltica, MER087187; Shewanella woodyi, MER016525; Pseudoalteromonas sp. AS-11) in the MEROPS peptidase database http://merops. sanger.ac.uk (Rawlings and Barrett 1993) to assign the family for the identified protease and also in the NCBI database.

\section{Cloning and expression of protease encoding gene}

The complete ORF of the protease was amplified with the primers MP1F (5'-ATGCATAAGAAACATTTAATAGCA3') and MP1R (5'CTAGTAGCTTGCACTCAGCTGAAC-3') and cloned into pTZ57R/T vector, and the resultant plasmid was used to transform $E$. coli $\mathrm{DH} 5 \alpha$. The cloned protease gene was confirmed by DNA sequencing using the BigDye Terminator sequencing method and an ABI PRISM 3700 sequencer (Applied Biosystems, Foster City, CA). The protease gene was again amplified from the recombinant plasmid with and without the signal peptide using forward primers P1FS 5' - GCGCCATATGCATAAGAAACATTTAATAG-3' (NdeI site is underlined) and P1FWS 5' - ATTACATATGGAATACCAAGCGACTATGGTAAG-3' (NdeI site is underlined) and reverse primer
P1RH 5'-TAATAAGCTTGTAGCTTGCACTCAGCTG3' (HindIII site is underlined). The PCR product was digested with NdeI and HindIII and ligated with expression vector $\mathrm{pET} 30 \mathrm{~b}$ to obtain another recombinant plasmid, in which the protease gene was under the control of the T7 promoter. This recombinant plasmid was then used to transform E. coli BL21 (DE3). E. coli BL21 (DE3) carrying recombinant plasmid was grown overnight at $37^{\circ} \mathrm{C}$ in $\mathrm{LB}$ medium containing kanamycin $(30 \mu \mathrm{g} / \mathrm{ml})$. Fresh LB medium with kanamycin was inoculated with $1 \%(\mathrm{v} / \mathrm{v})$ of overnight culture and incubated at $37^{\circ} \mathrm{C}$ until the culture reached an absorbance of 0.4 at $\mathrm{OD}_{600}$. The culture was then induced with $0.1 \mathrm{mM}$ of isopropyl- $\beta$-D-thiogalactopyranoside (IPTG). The induced cells were harvested by centrifugation at $4^{\circ}$ $\mathrm{C}$ for $10 \mathrm{~min}$ at $12,000 \times \mathrm{g}$ and washed with $50 \mathrm{mM}$ Tris-buffer ( $\mathrm{pH} 7.5)$. The cells were then disrupted by sonication (five times for $30 \mathrm{~s}$ with $30 \mathrm{~s}$ interval) (Labsonic U, Germany), and centrifuged at $12000 \times g$ for $30 \mathrm{~min}$. Both the soluble and pellet fractions were analysed for protease activity.

\section{SDS-PAGE and Zymogram analysis}

The proteins from the insoluble fraction after sonication were resolved on Sodium dodecyl sulphate-polyacrylamide gel electrophoresis (SDS-PAGE) (Laemmli 1970). The gel was stained with Coomassie brilliant blue $\mathrm{R}-250$. The molecular mass of protein was determined by comparison with the mobility of molecular weight markers (Fermentas, Opelstrasse, Germany). For zymogram analysis, the protein were separated on the SDSPAGE with $0.1 \%(\mathrm{w} / \mathrm{v})$ gelatin in the separating gel (Bressollier et al. 1999). After electrophoresis, the gel was incubated with $2.5 \%(\mathrm{v} / \mathrm{v})$ Triton $\mathrm{X}-100$ at $37^{\circ} \mathrm{C}$ for $30 \mathrm{~min}$ for the removal of SDS followed by another round of incubation in $50 \mathrm{mM}$ Tris $(\mathrm{pH} \mathrm{7.4)}$ ) for $30 \mathrm{~min}$. The gel was then incubated in the same buffer at $37^{\circ} \mathrm{C}$ for $4 \mathrm{~h}$. Zone of clearance within the gel was checked after staining with Coomassie brilliant blue R-250.

\section{Purification of protease}

The cell pellets was resuspended in $20 \mathrm{mM}$ Tris- $\mathrm{HCl}$ buffer $(\mathrm{pH} 7.5)$, disrupted by sonication and centrifuged at $10,000 \times \mathrm{g}$ for $30 \mathrm{~min}$. The insoluble fraction after sonication, containing the recombinant protein was collected and solubilised in $3 \mathrm{ml}$ of cold $2 \mathrm{M}$ urea containing $20 \mathrm{mM}$ Tris- $\mathrm{HCl}$ buffer, $0.5 \mathrm{M} \mathrm{NaCl}$ and $2 \%$ Triton $\mathrm{X}-100(\mathrm{pH} 8.0)$ and centrifuged at $10,000 \times \mathrm{g}$ for $10 \mathrm{~min}$. The supernatant was discarded and the pellet fraction was further washed once with the same buffer and then resuspended in $5 \mathrm{ml}$ of $20 \mathrm{mM}$ Tris- $\mathrm{HCl}$ buffer containing $8 \mathrm{M}$ urea, $0.5 \mathrm{M} \mathrm{NaCl}, 5 \mathrm{mM}$ imidazole, $1 \mathrm{mM}$ 2-mercaptoethanol ( $\mathrm{pH} 8.0$ ), and stirred at room temperature for $30-60 \mathrm{~min}$ to solubilise the recombinant 
protein. The solubilised proteins were passed through Ni-NTA Affinity column (Sigma Chemicals, USA) and eluted with imidazole following the manufacturer's recommendation. The purified protein with urea was then refolded in $20 \mathrm{mM}$ Tris buffer by drop dilution method (Howarth et al. 2006). The refolded protein was used for further characterization.

\section{Enzyme assay}

In standard conditions, the reaction mixture contained $480 \mu \mathrm{l}$ of $1 \%\left(\mathrm{w} / \mathrm{v}\right.$ ) azocasein, $2 \mathrm{mM} \mathrm{CaCl}_{2}$ and appropriate dilution of enzyme in $50 \mathrm{mM}$ Tris buffer, $\mathrm{pH} 7.5$ (Radha and Gunasekaran 2007). The reaction mixture was incubated at $37^{\circ} \mathrm{C}$ for $30 \mathrm{~min}$. The reaction was terminated by adding $600 \mu \mathrm{l}$ of $10 \%(\mathrm{w} / \mathrm{v})$ trichloroacetic acid and kept on ice for $15 \mathrm{~min}$ followed by centrifugation at $15,000 \times \mathrm{g}$ at $4{ }^{\circ} \mathrm{C}$ for $10 \mathrm{~min}$. Eight hundred microlitre of the supernatant were neutralized by adding $200 \mu \mathrm{l}$ of $1.8 \mathrm{~N} \mathrm{NaOH}$, and the absorbance at $420 \mathrm{~nm}$ $\left(\mathrm{A}_{420}\right)$ was measured using a spectrophotometer (Hitachi U-2000, Japan). The control samples were the extract from the E. coli BL21 (pET30b) only. One unit of protease activity was defined as the amount of enzyme required to yield an increase in absorbance of 0.01 at $\mathrm{A}_{420}$ in $30 \mathrm{~min}$ at $37^{\circ} \mathrm{C}$.

\section{Effect of metal ions, inhibitors, solvents, detergents and reducing agents}

Protease was purified as previously described followed by extensive dialysis in the presence of $10 \mathrm{mM}$ EDTA in $50 \mathrm{mM}$ Tris buffer ( $\mathrm{pH} \mathrm{7.5)}$ and then, the enzyme was assayed under standard conditions in the presence of different metal ions $\left(\mathrm{Mn}^{2+}, \mathrm{Ca}^{2+}, \mathrm{Co}^{2+}, \mathrm{Ni}^{2+}, \mathrm{Hg}^{2+}\right.$ and $\left.\mathrm{Zn}^{2+}\right)$. The purified protease was pre-incubated with different metal ions $(0.1,1$ and $5 \mathrm{mM})$, inhibitors $(5 \mathrm{mM})$, detergents $(0.5-1 \%)$ and reducing agent $(\beta-\mathrm{ME})$ $(5 \mathrm{mM})$ for $15 \mathrm{~min}$ at $37^{\circ} \mathrm{C}$. The residual activity was measured under standard assay condition.

\section{Physicochemical characterization}

The effect of temperature on the activity of the purified AS-protease was determined at the temperature range of $10^{\circ} \mathrm{C}$ to $85^{\circ} \mathrm{C}$ at $\mathrm{pH} 7.5$. Thermal stability of the purified AS-protease was estimated by incubating the enzyme in $50 \mathrm{mM}$ Tris buffer at different temperatures $\left(35^{\circ} \mathrm{C}, 45^{\circ} \mathrm{C}\right.$ and $\left.55^{\circ} \mathrm{C}\right)$ in the presence of $5 \mathrm{mM} \mathrm{CoCl}_{2}$. At different intervals, samples were withdrawn and the residual activity was measured under standard assay condition. The optimum $\mathrm{pH}$ of AS-protease activity was measured at $37^{\circ} \mathrm{C}$ with different buffer: $50 \mathrm{mM}$ Sodium acetate buffer ( $\mathrm{pH}$ 4-5.5), $50 \mathrm{mM}$ Tris buffer ( $\mathrm{pH}$ 6.58.5), $50 \mathrm{mM}$ sodium carbonate buffer $(\mathrm{pH} 9)$, and 50 $\mathrm{mM}$ glycine- $\mathrm{NaOH}$ buffer ( $\mathrm{pH}$ 10.5-12.5).

\section{Determination of kinetic parameters}

The recombinant protease was assayed with $0.1-10 \mathrm{mg} /$ $\mathrm{ml}$ azocasein in $50 \mathrm{mM}$ Tris buffer $(\mathrm{pH} \mathrm{7.5)}$ containing $5 \mathrm{mM} \mathrm{Co}^{2+}$ at $42^{\circ} \mathrm{C}$ for $10 \mathrm{~min}$. Kinetic parameters, such as $K_{\mathrm{m}}(\mathrm{mg} / \mathrm{ml}) K_{\text {cat }}\left(\mathrm{min}^{-1}\right)$ and $\mathrm{V}_{\max }(\mathrm{U} / \mathrm{mg}$ protein) for substrates were obtained using Line-weaver Burk plot.

\section{Results}

\section{Construction and screening of metagenomic library from Goat skin}

Diverse microbial population (both culturable and non culturable) with majority of them with proteolytic activity was found on the goat skin surface (Kayalvizhi and Gunasekaran, 2008). Therefore, metagenomic DNA $(\sim 5 \mu \mathrm{g} / \mathrm{ml})$ of the goat skin surface was isolated by an indirect extraction method as described in materials and methods. A small-insert metagenomic library in pUC19 was constructed. Analysis of the randomly selected recombinant clones revealed that the clones had the insert DNA of an average size of $\sim 3.2 \mathrm{~kb}$.

Screening of 70,000 recombinant clones for proteolytic activity revealed one clone carrying recombinant plasmid designated as pSP1 that exhibited a zone of clearance on LB skim milk agar plate after $36 \mathrm{~h}$ of incubation at $37^{\circ} \mathrm{C}$ (Figure 1). Since insert DNA in this clone was $3.8 \mathrm{~kb}$ (Figure 2), the protease gene could have been expressed with its own promoter (Figure 3 ). Transposon mutagenesis on pSP1 was carried out to have $\mathrm{Tn}$ insertion within the protease coding region in the insert DNA (Figure 2). Randomly selected transposon carrying protease negative mutants were sequenced and alignment of these sequences lead to the identification of the protease open reading frame (ORF).

\section{Analysis of the cloned protease gene}

The ORF encoding the protease was amplified and cloned in $\mathrm{pTZ}$ 57R/T vector and the resultant construct was designated as pTSP1. Analysis of the insert DNA sequence as described above, revealed an ORF (1890 bp) with ATG as start codon and TAG as termination codon. The deduced amino acid sequence of the protease comprises of 630 amino acids and an estimated molecular mass of 65,540 Da. Multiple sequence alignment of this protease was performed with other known protease sequences in the NCBI database and shown in Figure 4. The amino acid sequence of this AS-protease displayed 98\% sequence similarity with uncharacterized proteases of various Shewanella sp. in the NCBI database and a maximum of $85 \%$ similarity with S8A secreted peptidaseA of Shewanella baltica MEROPS database (Rawlings and Barrett 1993). These results suggested that the cloned protease belongs to serine family peptidase. 


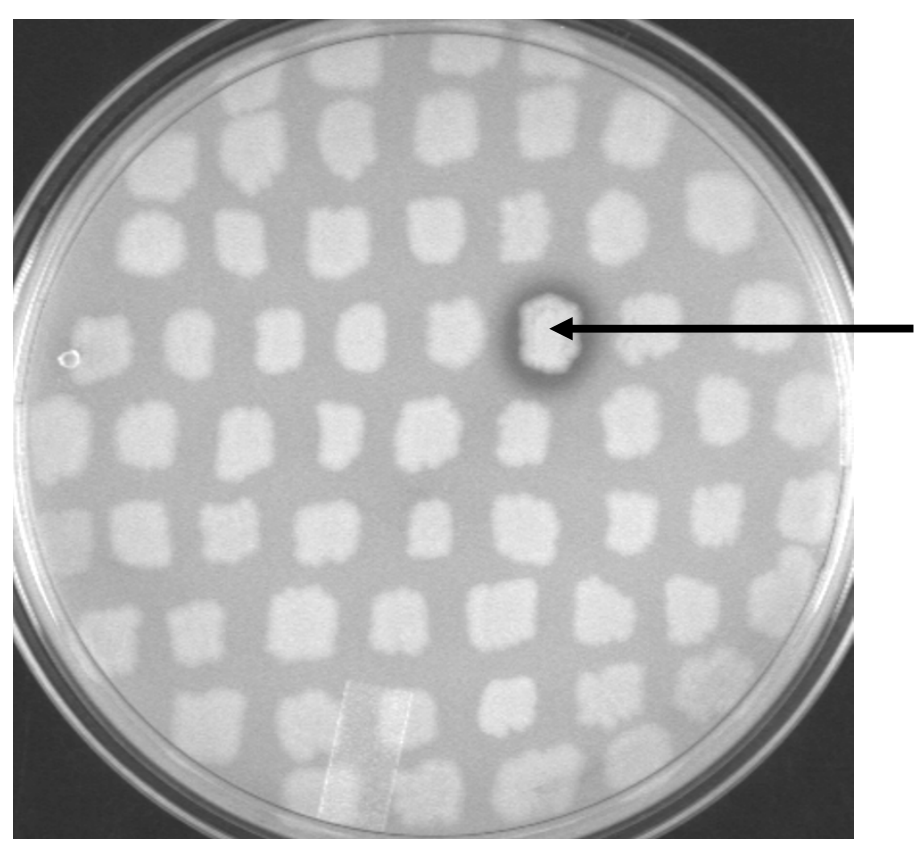

\section{Protease positive clone}

Figure 1 Functional screening of metagenomic library for protease activity on skim milk agar plate. Metagenomic library consisting of 70,000 clones were screened on skim milk plate for protease activity. The positive clone showing zone of clearance in skim milk agar plate is indicated by an arrow.

At the $\mathrm{N}$ terminus of this AS-protease sequence, presence of a signal peptide with 23 amino acids was predicted using the SignalP program (Bendtsen et al. 2004). The Pfam analysis of this protease showed a conserved catalytic domain of peptidase S8 family and two prepeptidase C-terminal domains. This AS-protease contained active site residues within the catalytic motif Asp-Thr/Ser-Gly, His-Gly-Thr-His and Gly-Thr-SerMet-Ala-X-Pro, which is characteristic of serine subfamily S8A. Results from the sequence analysis of this protease suggested it to be serine protease subfamily S8A.

\section{Expression of AS-protease gene}

The protease coding ORF was amplified and cloned into the expression vector pET30b and resultant recombinant plasmid was designated as pETP1. Upon induction, the E. coli BL21 (DE3) harbouring the recombinant plasmid pETP1 expressed the cloned protease gene.

Further, proteins in the recombinant cell extract was resolved on SDS-PAGE revealed an over expressed protein of $66 \mathrm{kDa}$ (Figure 5A) which is in agreement with the predicted molecular mass for the cloned ASprotease. The protein was expressed as inclusion bodies, which was later solubilised with urea as mentioned in materials and methods. The solubilised protein was purified on Ni-NTA Affinity Chromatography (Figure 5B) and then refolded by drop dilution. The purified refolded protein exhibited a maximum activity of $100.2 \mathrm{U} \mathrm{ml}^{-1}$ (specific activity $83.56 \mathrm{U} \mathrm{mg}^{-1}$ ).

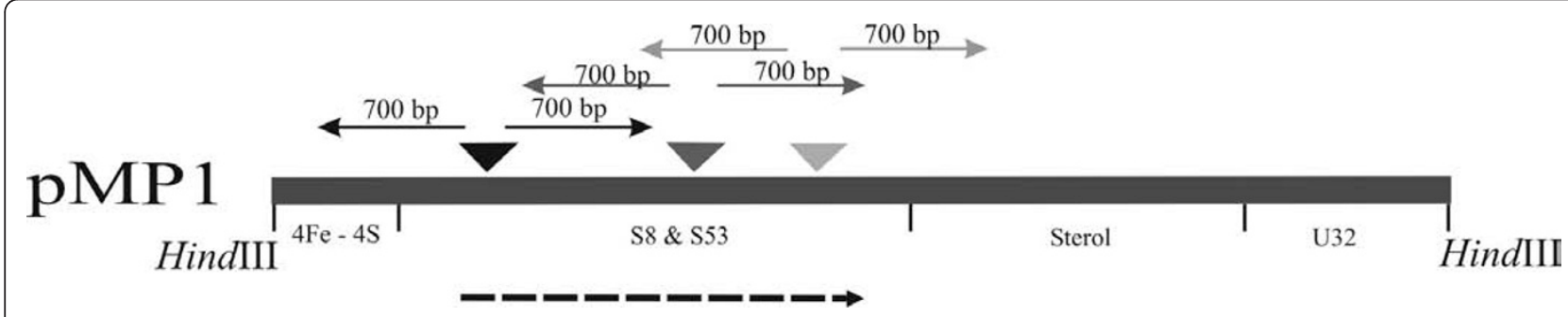

Figure 2 Schematic representation of the insert metagenomic DNA and the position of transposon used for sequencing the coding region. Each inverted triangle represents the individual insertion of transposon in the protease coding gene. Black dotted arrow indicates the orientation and location of protease gene. 4Fe-4S represents 4Fe-4S ferredoxin iron-sulfur binding domain protein, S8 \& S53 - peptidase S8 and S53 subtilisin kexin sedolisin, sterol - Sterol-binding domain protein, U32 - peptidase U32. 
Bacilli promoter SD AS-protease SD E.coli promoter

Bacilli promoter SD AS-protease SD E.coli promoter

$$
\begin{array}{r}
\text { Bacilli promoter SD } \\
\text { AS-protease SD } \\
\text { E.coli promoter }
\end{array}
$$

(1)

(1) 1

(1) TTCTCGgCGTTGAA----TGTGGgGGAAACA TCC.CATATACT -35 region

44

(22) CAAT---AAGGATGACTATTT-TGGTAAAATTCAGAATGTGAG (20) AACTGgGCAgGTTGAAAATACCTTCTACATtgGATtATGTCTC (44) GACG TACATGTTAATAGATGGCGTGAAGCACAGTCGTGTCAT -10 region

(61) GAA-TCATCAАATACATATTCAAGAAAGGGAAGAGGAGAATG

(63) GAAGTCTGTGGAGACATAAA-AAGAAAATGGAGTTCAACATG

(86) TTACCTGGCGGAAATTAAACTAAGAGAGAGCTCT-----ATG

\section{SD}

Figure 3 Comparison of AS-protease promoter with other promoter sequences. A probable promoter regions $(-35,-10$ region) and a Shine-Dalgarno (SD) region is shown by solid lines and is highlighted. Bacilli protease promoter represents, Bacillus stearothermophilus protease promoter. Protease promoter represents the predicted alkaline serine protease promoter region. E. coli protease promoter represents, E.coli lon protease promoter.

\section{Effect of $\mathrm{pH}$ and temperature}

The effect of $\mathrm{pH}$ on the purified AS-protease was examined at $37^{\circ} \mathrm{C}$. Purified AS-protease exhibited maximum activity at $\mathrm{pH} 10.5$ (Figure 6A), confirming it to be an alkaline protease. This protease exhibited 75 $85 \%$ of activity at a $\mathrm{pH}$ range of 7.5 to 9.5 . The proteolytic activity was significantly decreased above $\mathrm{pH} 11.5$ and below $\mathrm{pH}$ 7.0. Proteolytic activity was found maximum at $42^{\circ} \mathrm{C}$ (Figure 6B) but exhibited only 65 and $85 \%$ of the maximum activity at the temperature range of $35^{\circ} \mathrm{C}$ and $55^{\circ} \mathrm{C}$ respectively. Thermal stability of the purified AS-protease was estimated at

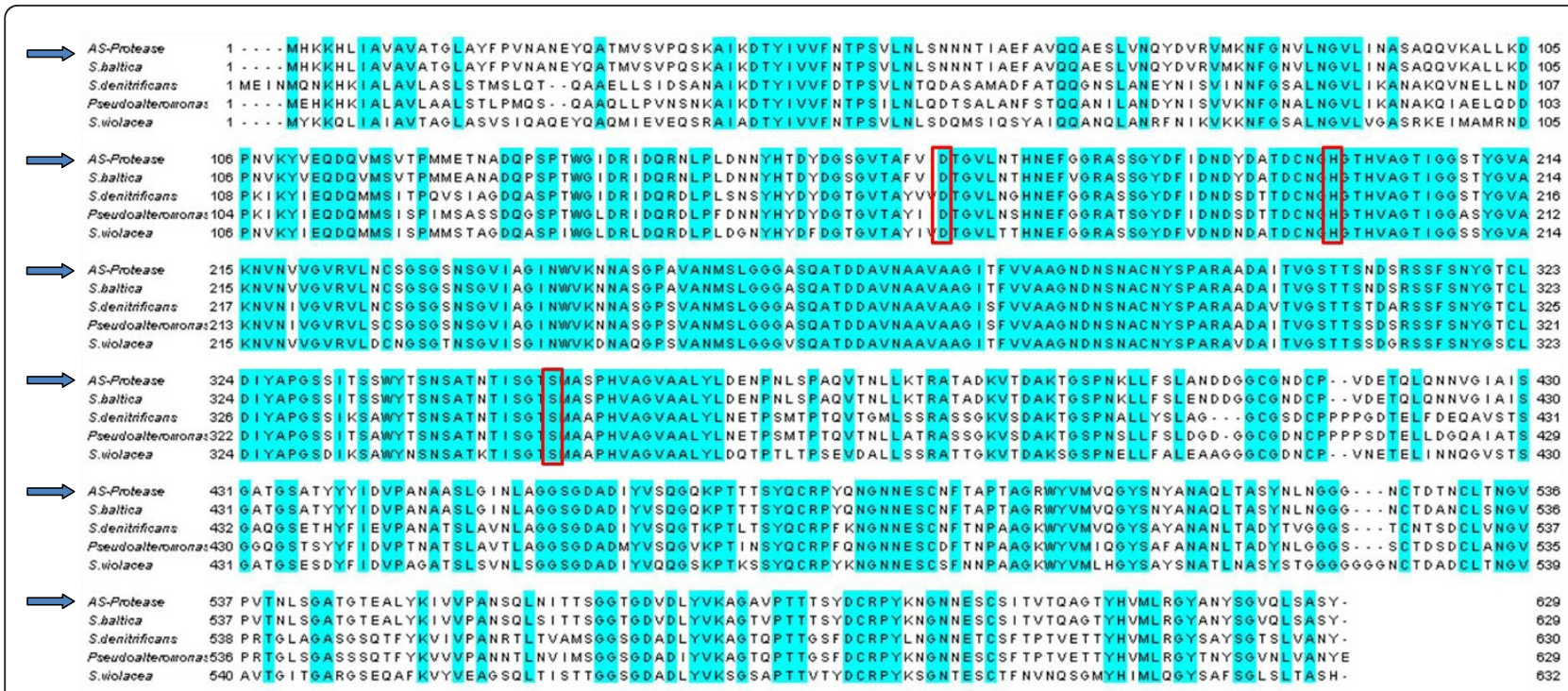

Figure 4 Multiple sequence alignment of AS-protease gene sequence from metagenome. Proteases used for alignment are S. baltica, peptidase S8 and S53 subtilisin kexin sedolisin [Shewanella baltica OS185] (YP_001367387.1); S. violacea, extracellular alkaline serine protease precursor, putative [Shewanella violacea DSS12] (YP_003556880.1); S. denitrificans, peptidase S8 and S53, subtilisin, kexin, sedolisin [Shewanella denitrificans OS217] (YP_562027.1). Pseudoalteromonas, extracellular alkaline serine protease 2 [Pseudoalteromonas sp. AS-11]. The AS-protease sequence identified from metagenome is indicated by arrows in the left. Conserved residues are letters in dark blue background. Catalytic residues are boxed in red outline. 


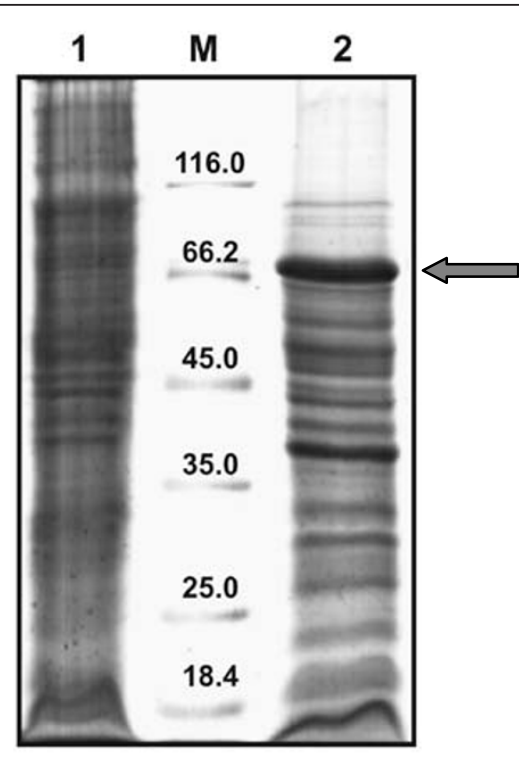

(A)

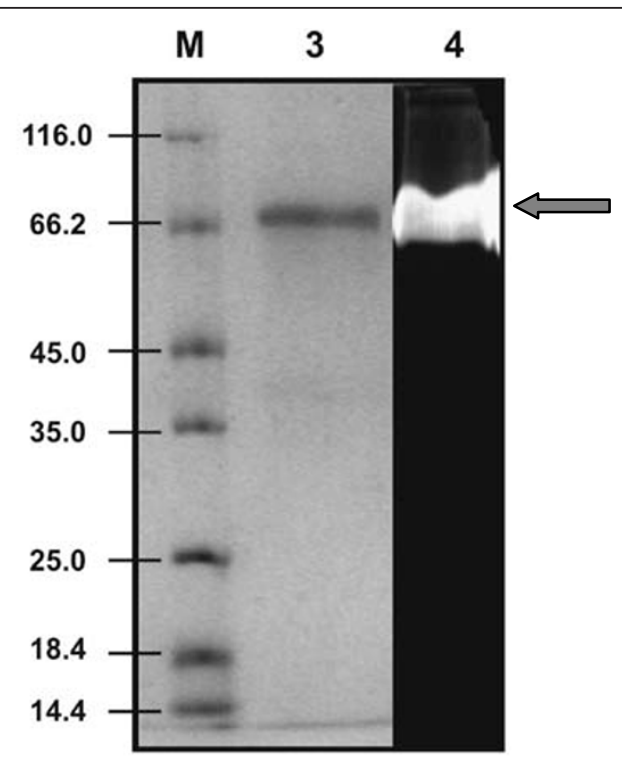

(B)

Figure 5 SDS-PAGE and zymogram analysis of the purified AS-protease. Lane M, molecular weight marker proteins (14.4 to 116 kDa); Solublised pellet fraction of E. coli BL21 (pET30b) (lane 1) and E. coli BL21 (pETP1) (lane 2); purified AS-protease (lane 3); zymogram of purified protease (lane 4). An arrow indicates the purified AS- protease.

different temperatures $\left(35^{\circ} \mathrm{C}, 45^{\circ} \mathrm{C}\right.$ and $\left.55^{\circ} \mathrm{C}\right)$ in the presence of $5 \mathrm{mM} \mathrm{CoCl}_{2}$ and activity was measured at $42^{\circ} \mathrm{C}$. The AS-protease was stable at $35^{\circ} \mathrm{C}$ for $60 \mathrm{~min}$. However, the stability of this protease decreased drastically between $45^{\circ} \mathrm{C}$ and $55^{\circ} \mathrm{C}$ with half-life of 60 and 20 min respectively (Figure 7 ).

\section{Effects of metal ions and additives}

The AS-protease activity was estimated in the presence of metal ions ( $5 \mathrm{mM})$ and different additives. Protease was purified as previously described without metal ions followed by extensive dialysis in the presence of $10 \mathrm{mM}$ EDTA. All metal ions at low concentrations $(0.1 \mathrm{mM}$ and $1 \mathrm{mM}$ ) did not affect significantly the protease activity. Even at $5 \mathrm{mM}$ concentration, $\mathrm{Zn}^{2+}, \mathrm{Hg}^{2+}$ and $\mathrm{Ni}^{2+}$ did not affect the protease activity whereas $\mathrm{Fe}^{2+}$ significantly inhibited protease activity. However, $\mathrm{Co}^{2+}$ and $\mathrm{Mn}^{2+}$ enhanced protease activity by 2.25 and 2 fold respectively (Table 2 ). This improved protease activity was not affected by the presence of EDTA.

\section{Substrate specificity}

The substrate specificity of AS-protease was examined by using different proteins (Casein, Bovine serine albumin $(B S A)$ and gelatin $[0.1 \% \mathrm{w} / \mathrm{v}])$ as substrate in the reaction mixtures. AS-protease exhibited relatively high activity on casein. But this protease exhibited only 55 and $58 \%$ activity on BSA and Gelatin substrates respectively.

\section{Kinetic parameters}

Initial velocities of the purified AS-protease on different concentrations of azocasein were determined under the standard assay conditions at $\mathrm{pH} 10.5$ (Figure 8). The Lineweaver-Burk plot was constructed and the calculated $\mathrm{V}_{\max }, K_{\mathrm{m}}$ and $k_{\text {cat }}$ for azocasein are $366 \mathrm{U} / \mathrm{mg}$, $0.13 \mathrm{mg} / \mathrm{ml}$ and $24,156 \mathrm{~min}^{-1}$ respectively.

\section{Nucleotide sequence accession number}

The nucleotide sequence of the AS-protease gene obtained from metagenome was deposited in the GenBank database under the accession number HM370566.

\section{Discussion}

In this study, an attempt was made to identify a protease gene from the goat skin surface metagenome. The eukaryotic DNA concentration was lower in the metagenomic DNA prepared using the indirect methods than the direct method (Gabor et al. 2003). Therefore, we have used indirect extraction method for the isolation of metagenomic DNA from goat skin surface and we were able to identify, overexpress, purify and characterize a protease gene by screening recombinant clones.

We have earlier reported that goat skin contains diverse species of bacteria including several unculturable bacteria in addition to the culturable proteolytic bacteria that are predominant and are involved in the degradation of the skin (Kayalvizhi and Gunasekaran 2008). This does not rule out the possible role of the 
(A)

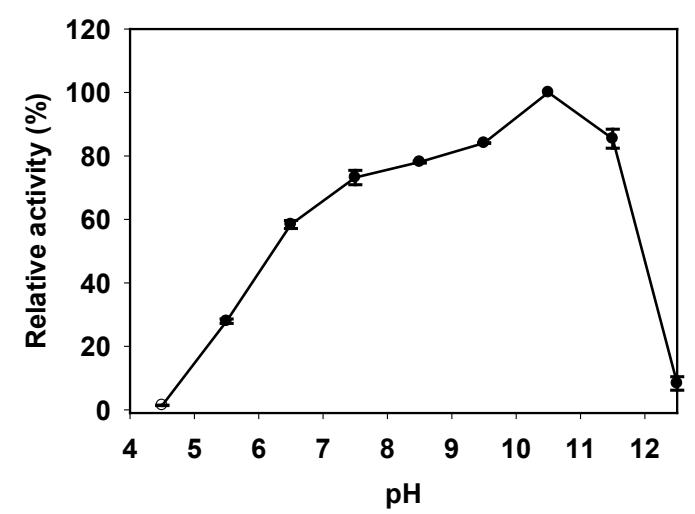

(B)

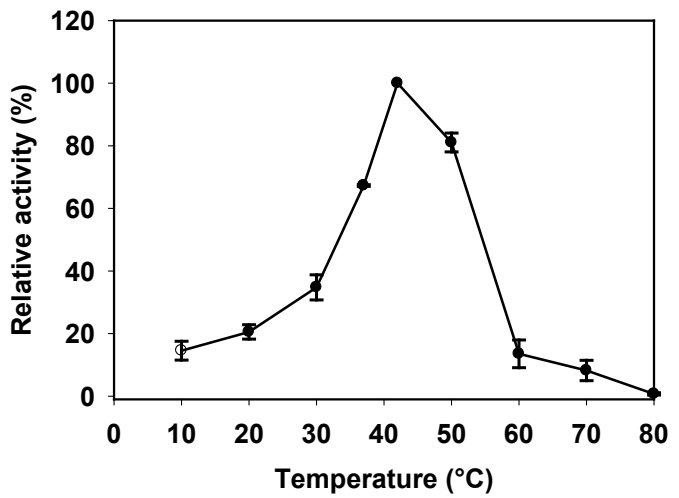

Figure 6 Effect of $\mathrm{pH}$ and temperature on the activity of ASprotease. The AS- protease activity was maximum at $\mathrm{pH} 10.5$ (A) and at temperature $42^{\circ} \mathrm{C}(\mathrm{B})$ and these values were taken as $100 \%$ for comparison. Each value represents the mean of triplicate measurements and varied from the mean by not more than $10 \%$.

unculturable bacteria in the degradation of the animal skin. Therefore, the goat skin surface was selected as DNA source for the construction of metagenomic library and to screen for protease gene. Identification of protease gene from metagenomic library was previously unsuccessful (Jones et al. 2007; Rondon et al. 2000). However, few other functional metalloproteases were identified through metagenomic approach (Lee et al. 2007; Waschkowitz et al. 2009; Gupta et al. 2002). The unsuccessful attempts in identification of protease genes from metagenomic library could be attributed to the problems associated with the expression of cloned gene in the heterologous host (Handelsman 2004) and low frequency of target sequence in the metagenomic library (Henne et al. 1999). The serine protease gene identified in the present study showed maximum similarity with peptidase S8 and S53 subtilisin kexin and sedolisin from S. baltica. Though the sequence from $S$. baltica is available in the NCBI database, there are no reports on the functional characterization of the peptidase S8 and S53 subtilisin kexin and sedolisin

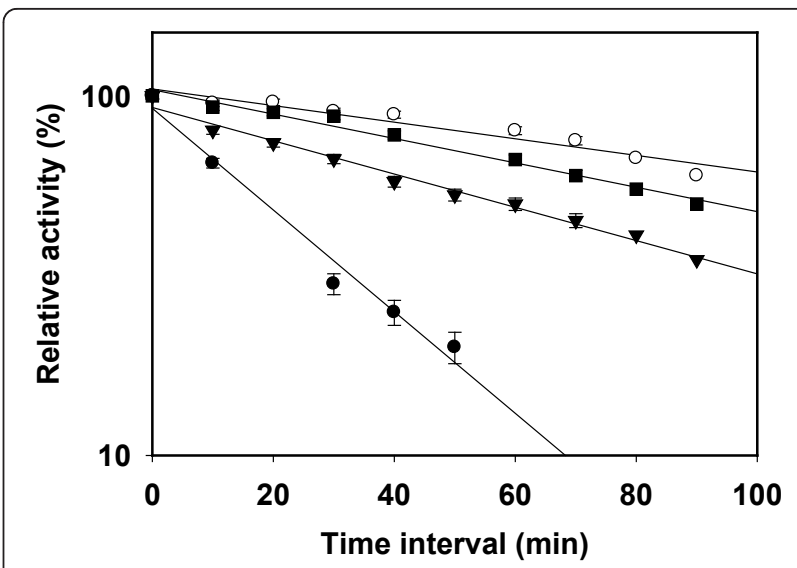

Figure 7 Thermal stability profiles of the purified protease in the presence of $5 \mathrm{mM} \mathrm{Co2+}$ at $55^{\circ} \mathrm{C}(\bullet), 45^{\circ} \mathrm{C}(\nabla), 40^{\circ} \mathrm{C}(-)$ and $35^{\circ} \mathrm{C}(\circ)$. Residual activity was measured at standard conditions.

from S. baltica. MEROPS database search confirmed that the AS-protease belongs to serine protease S8A family (Jaton-Ogay et al. 1992; Larsen et al. 2006). Based on the multiple sequence alignment, it was found that the catalytic amino acids are conserved as a catalytic triad (D165, H198 and S350) as found in other proteases (Larsen et al. 2006; Rawlings and Barrett 1993).

The metagenome insert sequence was similar to the sequence found in different strains of Shewanella, suggesting that the insert from metagenome could have been derived from a strain of Shewanella sp. Majority of Shewanella sp. are of marine origin (Fredrickson et al. 2008), among which few species are involved in spoilage of fish under stored conditions (Jorgensen and Huss 1989). Thus

Table 2 Effect of inhibitors, metal ions and solvents on AS-protease activity

\begin{tabular}{ll}
\hline Additives & Relative activity (\%) \\
\hline None & 100 \\
PMSF (5 mM) & 22 \\
EDTA (5 mM) & 100 \\
DTT (5 mM) & 38 \\
$\beta$-ME (5 mM) & 38 \\
DMSO (1\%) & 34 \\
$\mathrm{SDS}_{(0.5 \%)}$ & 26 \\
$\left.\mathrm{IsO}_{-} \mathrm{propanol}^{2} \%\right)$ & 125 \\
$\mathrm{MnCl}_{2}(5 \mathrm{mM})$ & 200 \\
$\mathrm{CaCl}_{2}(5 \mathrm{mM})$ & 138 \\
$\mathrm{CoCl}_{2}(5 \mathrm{mM})$ & 225 \\
$\mathrm{NiSO}_{4}(5 \mathrm{mM})$ & 109 \\
$\mathrm{FeSO}_{4}(5 \mathrm{mM})$ & 27 \\
$\mathrm{HgCl}_{2}(5 \mathrm{mM})$ & 113 \\
$\mathrm{ZnCl}_{2}(5 \mathrm{mM})$ & 94 \\
\hline $\mathrm{The} \mathrm{purfied}^{2}$ &
\end{tabular}

The purified AS-protease was preincubated with inhibitors, metal ions or additives/solvents for $15 \mathrm{~min}$ at $37^{\circ} \mathrm{C}$. The activity of protease measured without any additive was set as $100 \%$. 


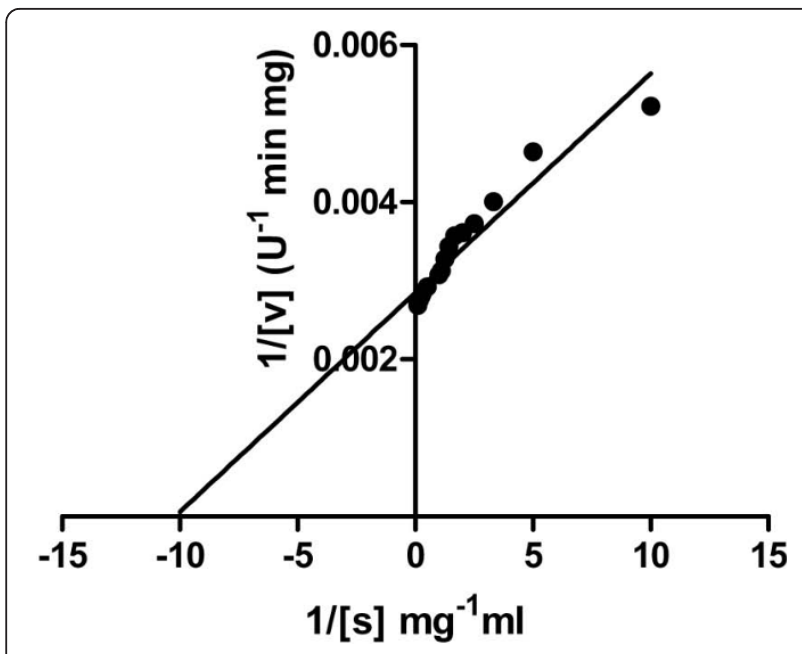

Figure 8 Lineweaver-Burk plot of the AS- protease. The Lineweaver-Burk plot was made from the results of the protease assay using different concentrations of azocaesin as substrate under standard conditions. The calculated Vmax and $\mathrm{Km}$ for azocasein are $366 \mathrm{U} / \mathrm{mg}$ and $0.13 \mathrm{mg} / \mathrm{ml}$ respectively.

it is presumed that members of Shewanella sp. are present in the microbiome of the goat skin during degradation. Members of Shewanella sp. are Gram-negative bacteria belonging to the class Gammaproteobacteria. Significant similarity between Shewanella and E. coli could be responsible for the possible expression of cloned gene heterologous system.

Although AS-protease gene was expressed, this protease was produced as inclusion bodies in E. coli when it was overexpressed. Similar expression was seen with subtilisin-like protease gene from Shewanella sp. (Kulakova et al. 1999). A lipase gene from a metagenome was also reported to be overexpressed in E. coli (Park et al. 2007) and produced as inclusion bodies. In this case, the lipase activity was detected in zymogram. In the present study, the AS- protease in the inclusion bodies was inactive but was solubilised and purified under denaturing conditions. The purified AS-protease was then refolded by drop dilution method to recover its activity. Similarly, cysteine proteinase of E. histolytica was recovered from the inclusion bodies (Quintas-Granados et al. 2009).

Alkaline proteases find a number of applications in food industry (Neklyudov et al. 2000), leather processing industry (Varela et al. 1997), waste management (Dalev 1994), medical applications (Kudrya and Simonenko 1994). Proteases are used in detergents and cleaning agent for a long time (Sakiyama et al. 1998; Showell 1999). The purified metagenomic AS-protease showed maximum activity at $\mathrm{pH} 10.5$ suggesting that it is an alkaline protease (Larsen et al. 2006; Moreira et al. 2003). The purified protease was inhibited by phenyl methyl sulfonyl fluride (PMSF), which is a characteristic nature of serine protease (Gupta et al. 2002; Moreira et al. 2003; Xiaoqing Zhang et al. 2010). DTT, $\beta$-ME and DMSO were found to inhibit the protease activity, as observed with property of other proteases (Sierecka 1998). In general, most of the serine proteases show enhanced activity in the presence of $\mathrm{Ca}^{2+}$ (Dodia et al. 2008; Singh et al. 2001). In our study, $\mathrm{Co}^{2+}$ and $\mathrm{Mn}^{2+}$ had improved the AS-protease activity by 2.5 and 2 fold respectively. These metal ions may be important cofactors for the proteolytic activity of the enzyme (Ghorbel et al. 2003; Kumar and Takagi 1999).

The largest share of the enzyme market is occupied by detergent resistant proteases which are active and stable in the alkaline $\mathrm{pH}$ range (Gupta et al. 2002). The Serine proteases of S8A (subtilisin-like) are generally used in laundry and detergent industries. Hence, the identified AS-protease with maximum activity at alkaline $\mathrm{pH}$ range of 10.5 will find application in the detergent and laundry industries. Also metal ions play an important role in enhancing the enzyme activity. According to earlier reports, $\mathrm{Ca}^{2+}$ enhanced the protease activity (Dodia et al. 2008; Singh et al. 2001) and stability. We report here for the first time that $\mathrm{Co}^{2+}$ enhances the protease activity. Hence, AS-protease in the presence of $\mathrm{Co}^{2+}$ can be used in detergent industries.

In summary, functional screening of the metagenomic library revealed a protease positive clone. The sequence analysis and enzyme assay strongly suggested that this alkaline protease is a member of serine protease family. This AS-protease is ready for detailed investigation such as X-ray crystallography and protein engineering studies to understand the molecular mechanism of its activity. Thus, the functional metagenomics pave the way to discover novel genes for biotechnological applications.

\section{Acknowledgements}

Authors thank Department of Biotechnology, New Delhi, India for the financial support through a grant (BT/PR- 8346/BCE/08/489/2006). PLP and TR thank University Grants Commission, New Delhi, India for the research fellowship under the scheme for meritorious students in Biosciences (F.No. 4-1/2006(BSR)/5-67/2007). The Centre for Advanced studies in Functional Genomics, Centre for Excellence in Genomic Sciences and Networking Resource Centre in Biological Sciences are gratefully acknowledged for support facilities.

Received: 24 December 2010 Accepted: 28 March 2011 Published: 28 March 2011

\section{References}

Altschul SF, Gish W, Miller W, Myers EW, Lipman DJ (1990) Basic local alignment search tool. J Mol Biol 215:403-410

Bendtsen JD, Nielsen H, von Heijne G, Brunak S (2004) Improved prediction of signal peptides: SignalP 3.0. J Mol Biol 340:783-795

Bressollier P, Letourneau F, Urdaci M, Verneuil B (1999) Purification and characterization of a keratinolytic serine proteinase from Streptomyces albidoflavus. Appl Environ Microbiol 65:2570-2576

Cottrell MT, Moore JA, Kirchman DL (1999) Chitinases from uncultured marine microorganisms. Appl Environ Microbiol 65:2553-2557 
Dalev PG (1994) Utilization of waste feathers from poultry slaughter for production of a protein concentrate. Bioresour Technol 48:265-267

Dodia MS, Rawal CM, Bhimani HG, Joshi RH, Khare SK, Singh SP (2008) Purification and stability characteristics of an alkaline serine protease from a newly isolated Haloalkaliphilic bacterium sp. AH-6.J Ind Microbiol Biotechnol 35:121-131

Fredrickson JK, Romine MF, Beliaev AS, Auchtung JM, Driscoll ME, Gardner TS, Nealson KH, Osterman AL, Pinchuk G, Reed JL, Rodionov DA, Rodrigues JL, Saffarini DA, Serres MH, Spormann AM, Zhulin IB, Tiedje JM (2008) Towards environmental systems biology of Shewanella. Nat Rev Microbiol 6:592-603

Gabor EM, de Vries EJ, Janssen DB (2003) Efficient recovery of environmental DNA for expression cloning by indirect extraction methods. FEMS Microbiol Ecol 44:153-163

Ghorbel B, Sellami-Kamoun A, Nasri M (2003) Stability studies of protease from Bacillus cereus BG1. Enzyme Microb Technol 32:513-518

Gupta R, Beg QK, Lorenz P (2002) Bacterial alkaline proteases: molecular approaches and industrial applications. Appl Microbiol Biotechnol 59:15-32

Handelsman J (2004) Metagenomics: application of genomics to uncultured microorganisms. Microbiol Mol Biol Rev 68:669-685

Henne A, Daniel R, Schmitz RA, Gottschalk G (1999) Construction of environmental DNA libraries in Escherichia coli and screening for the presence of genes conferring utilization of 4-hydroxybutyrate. Appl Environ Microbiol 65:3901-3907

Howarth M, Chinnapen DJ, Gerrow K, Dorrestein PC, Grandy MR, Kelleher NL, ElHusseini A, Ting AY (2006) A monovalent streptavidin with a single femtomolar biotin binding site. Nat Methods 3:267-273

Jaton-Ogay K, Suter M, Crameri R, Falchetto R, Fatih A, Monod M (1992) Nucleotide sequence of a genomic and a CDNA clone encoding an extracellular alkaline protease of Aspergillus fumigatus. FEMS Microbiol Lett 71:163-168

Jones BV, Sun F, Marchesi JR (2007) Using skimmed milk agar to functionally screen a gut metagenomic library for proteases may lead to false positives. Lett Appl Microbiol 45:418-420

Jorgensen BR, Huss HH (1989) Growth and activity of Shewanella putrefaciens isolated from spoiling fish. Int J Food Microbiol 9:51-62

Kayalvizhi N, Gunasekaran P (2008) Production and characterization of a lowmolecular-weight bacteriocin from Bacillus licheniformis MKU3. Lett Appl Microbiol 47:600-607

Kudrya VA, Simonenko IA (1994) Alkaline serine proteinase and lectin isolation from the culture fluid of Bacillus subtilis. Appl Microbiol Biotechnol 41:505-509

Kulakova L, Galkin A, Kurihara T, Yoshimura T, Esaki N (1999) Cold-active serine alkaline protease from the psychrotrophic bacterium Shewanella strain AC10: Gene cloning and enzyme purification and characterization. Appl Environ Microbiol 65:611-617

Kumar CG, Takagi H (1999) Microbial alkaline proteases: from a bioindustrial viewpoint. Biotechnol Adv 17:561-594

Laemmli UK (1970) Cleavage of structural proteins during the assembly of the head of bacteriophage T4. Nature 227:680-685

Larsen AN, Moe E, Helland R, Gjellesvik DR, Willassen NP (2006) Characterization of a recombinantly expressed proteinase K-like enzyme from a psychrotrophic Serratia sp. FEBS J 273:47-60

Lee DG, Jeon JH, Jang MK, Kim NY, Lee JH, Kim SJ, Kim GD, Lee SH (2007) Screening and characterization of a novel fibrinolytic metalloprotease from a metagenomic library. Biotechnol Lett 29:465-472

Lee SW, Won K, Lim HK, Kim JC, Choi GJ, Cho KY (2004) Screening for novel lipolytic enzymes from uncultured soil microorganisms. Appl Microbiol Biotechnol 65:720-726

Moreira KAP, Teixeira TS, MFS Porto, ALF Lima Filho JL (2003) New alkaline protease from Nocardiopsis sp.: partial purification and characterization. Process Biochemistry 39:67-72

Neklyudov AD, Ivankin AN, Berdutina AV (2000) Properties and uses of protein hydrolysates. Appl Biochem Microbiol 36:452-459

Page MJ, Di Cera E (2008) Serine peptidases: classification, structure and function. Cell Mol Life Sci 65:1220-1236

Park HJ, Jeon JH, Kang SG, Lee JH, Lee SA, Kim HK (2007) Functional expression and refolding of new alkaline esterase, EM2L8 from deep-sea sediment metagenome. Protein Expr Purif 52:340-347

Quintas-Granados LI, Orozco E, Brieba LG, Arroyo R, Ortega-Lopez J (2009) Purification, refolding and autoactivation of the recombinant cysteine proteinase EhCP112 from Entamoeba histolytica. Protein Expr Purif 63:26-32
Radha S, Gunasekaran P (2007) Cloning and expression of keratinase gene in Bacillus megaterium and optimization of fermentation conditions for the production of keratinase by recombinant strain. J Appl Microbiol 103:1301-1310

Rao MB, Tanksale AM, Ghatge MS, Deshpande W (1998) Molecular and biotechnological aspects of microbial proteases. Microbiol Mol Biol Rev 62:597-635

Rawlings ND, Barrett AJ (1993) Evolutionary families of peptidases. Biochem J 290(Pt 1):205-218

Rhee JK, Ahn DG, Kim YG, Oh JW (2005) New thermophilic and thermostable esterase with sequence similarity to the hormone-sensitive lipase family, cloned from a metagenomic library. Appl Environ Microbiol 71:817-825

Robertson DE, Chaplin JA, DeSantis G, Podar M, Madden M, Chi E, Richardson T, Milan A, Miller M, Weiner DP, Wong K, McQuaid J, Farwell B, Preston LA, Tan X, Snead MA, Keller M, Mathur E, Kretz PL, Burk MJ, Short JM (2004) Exploring nitrilase sequence space for enantioselective catalysis. Appl Environ Microbiol 70:2429-2436

Rondon MR, August PR, Bettermann AD, Brady SF, Grossman TH, Liles MR, Loiacono KA, Lynch BA, MacNeil IA, Minor C, Tiong CL, Gilman M, Osburne MS, Clardy J, Handelsman J, Goodman RM (2000) Cloning the soil metagenome: a strategy for accessing the genetic and functional diversity of uncultured microorganisms. Appl Environ Microbiol 66:2541-2547

Sakiyama T, Kabayama M, Tomita M, Nakamura J, Mukai H, Tomita Y, Furukawa K (1998) Distribution of glycoproteins with beta-N-acetylgalactosaminylated Nlinked sugar chains among bovine tissues. Biochim Biophys Acta 1380:268-274

Sambrook J, Fritsch EF, Maniatis T (1989) Molecular cloning. A 622 Laboratory Manual. Cold Spring Harbor NY: Cold Spring 623 Harbor Laboratory

Schloss PD, Handelsman J (2003) Biotechnological prospects from metagenomics. Curr Opin Biotechnol 14:303-310

Showell MS (1999) Enzymes, detergent. In: Flickinger MC, Drew SW (eds) Encyclopedia of bioprocess technology: fermentation, biocatalysis and bioseparation 2:958-971

Sierecka JK (1998) Purification and partial characterization of a neutral protease from a virulent strain of Bacillus cereus. Int J Biochem Cell Biol 30:579-595

Singh J, Vohra RM, Sahoo DK (2001) Purification and characterization of two extracellular alkaline proteases from a newly isolated obligate alkalophilic Bacillus sphaericus. J Ind Microbiol Biotechnol 26:387-393

Varela H, Ferrari MD, Belobradjic L, Vazquez A, Loperena ML (1997) Skin unhairing proteases of Bacillus subtilis: production and partial characterization. Biotechnol Lett 19:755-758

Voget S, Leggewie C, Uesbeck A, Raasch C, Jaeger KE, Streit WR (2003) Prospecting for novel biocatalysts in a soil metagenome. Appl Environ Microbiol 69:6235-6242

Waschkowitz T, Rockstroh S, Daniel R (2009) Isolation and characterization of metalloproteases with a novel domain structure by construction and screening of metagenomic libraries. Appl Environ Microbiol 75:2506-2516

Xiaoqing Zhang QL, Zhang Guoging, Wanga Hexiang, Ng Tzibun (2010) Purification and molecular cloning of a serine protease from the mushroom Hypsizigus marmoreus. Process Biochemistry 45:724-730

doi:10.1186/2191-0855-1-3

Cite this article as: Pushpam et al:: Identification and characterization of alkaline serine protease from goat skin surface metagenome. $A M B$ Express 2011 1:3.

\section{Submit your manuscript to a SpringerOpen ${ }^{\circ}$ journal and benefit from:}

- Convenient online submission

- Rigorous peer review

- Immediate publication on acceptance

- Open access: articles freely available online

- High visibility within the field

- Retaining the copyright to your article

Submit your next manuscript at $\gg$ springeropen.com 